\title{
Jejak Karawitan dalam Kakawin Sumanasantaka
}

\author{
Hendra Santosa, Dyah Kustiyanti, I Komang Sudirga \\ Jurusan Karawitan, Jurusan Tari, \\ Fakultas Seni Pertunjukan, \\ Institut Seni Indonesia (ISI) Denpasar \\ Jalan Nusa Indah Denpasar 80235 \\ Email: hendrasnts@gmail.com
}

\begin{abstract}
Kakawin Sumanasāntaka (Death Because Sumanasa Flowers) is one source of the search trail musical term of from about 22 manuscript Old Javanese literature. This article is part of the research entitled "Traces Track Karawitan in Ancient Java Script: Assessment Form, function and meaning". This discussion is intended to clarify the form and function of musical instruments during the period in East Java around the 10th century. This study uses historical method which, through the stages of heuristics, criticism, interpretation, and historiography. At this stage of heuristics used kakawin Sumanasāntaka is the work of Worsley, P., S. Supomo, M. Fletchert dan T.H. Hunter., year 2014 also found written entitled Kakawin Sumanasāntaka, Mati Karena Bunga Sumanasa, Karya Mpu Monaguna., Kajian sebuah puisi epik Jawa Kuno. Jakarta: Yayasan Obor Indonesia. Criticism is done internally through direct translation as the facts speak and the last is the stage of historiography. Form and function in kakawin Sumanasantaka musical instruments, can not be separated from the function of musical instruments in the future, namely as a means Javanese ceremonies and as accompanist secular activities.
\end{abstract}

Keywords: form, function, karawitan, kakawin, Sumanasāntaka

\begin{abstract}
ABSTRAK
Kakawin Sumanasāntaka (Mati Karena Bunga Sumanasa) merupakan salah satu sumber penelusuran jejak istilah karawitan dari sekitar 22 Naskah kesusastraan berbahasa Jawa Kuno awal. Tulisan ini merupakan bagian dari hasil penelitian yang berjudul "Melacak Jejak Karawitan dalam Naskah Jawa Kuno: Kajian Bentuk, fungsi, dan Makna". Pembahasan ini dimaksudkan untuk memperjelas bentuk dan fungsi instrumen musik pada masa periode Jawa Timur sekitar abad ke-10. Penelitian ini menggunakan metode sejarah yaitu, melalui tahapan heuristik, kritik, interpretasi, dan historiografi. Pada tahap heuristik ditemukan sebuah kakawin Sumanasantaka yaitu karya Worsley, P., S. Supomo, M. Fletchert dan T.H. Hunter. Tahun 2014, ditemukan juga tulisan berjudul Kakawin Sumanasāntaka, Mati Karena Bunga Sumanasa, Karya Mpu Monaguna., Kajian sebuah puisi epik Jawa Kuno, Jakarta: Yayasan Obor Indonesia. Kritik dilakukan secara internal melalui terjemahan secara langsung sebagai fakta yang berbicara dan yang terakhir adalah tahap historiografi. Bentuk dan fungsi Instrumen karawitan dalam kakawin Sumanasāntaka, tidak terlepas dari fungsi instrumen musik pada masa Jawa Kuna yaitu sebagai sarana upacara dan sebagai pengiring kegiatan sekuler.
\end{abstract}

Kata kunci: bentuk, fungsi, karawitan, kakawin, Sumanasāntaka 


\section{PENDAHULUAN}

Penelitian tentang istilah karawitan dalam naskah-naskah kuno telah dilakukan oleh para peneliti terdahulu. Penelaahan yang paling lengkap dilakukan oleh Jaap Kunts dengan bukunya yang berjudul Hindu Javanese Musical Instruments, ia telah menuliskan instrumen musik berdasarkan prasasti, relief, dan kesusastraan Jawa Kuno. Tulisan ini memuat secara terinci mengenai instrumen gamelan pada periode Hindu Jawa dan Bali yang dikelompokkan ke dalam idiofon, membranofon, aerofon, dan chordofon. Nama instrumen didaftar secara runut meliputi asal naskah, tahun, letak dalam naskah, dan nama instrumen yang disebutkan. Namun, bentuk dan fungsi karawitan belum begitu detail dibahas. Oleh karenannya, tulisan ini akan lebih mengutamakan bentuk dan fungsi instrumen karawitan dalam kakawin Sumanasāntaka. Dalam syair-syairnya tersebut menyiratkan tentang fungsi dan makna instrumen karawitan pada masa Erlangga.

Jaap Kunts dalam bukunya Javanese Musical Instrument tahun 1968, mengungkapkan tentang berbagai istilah yang berkaitan dengan istilah karawitan Jawa. pada halaman 114 dan 115, yang mengambil Kakawin Sumanasāntaka dari Buku Juynboll II - H. H, Oud-Javanche-Nederlandshe Wooenlijst, Leiden 1923 (Kunst, 1968: 114 dan 131). Naskah Kakawin Sumanasāntaka yang diambil oleh Juynboll tidak diketahui karena bukunya belum terlacak. Kunts mengungkap istilah karawitan (namanama instrumen musik) dalam 13 syair Kakawin Sumanasāntaka yaitu istilah calung (XXVII 8), ganding/gěnding (XXXIX 2, CXIII 3), garantung (LII 2), mongmong (CXLIC 4), mrĕdangga (LII 6), padahi, rojeh dan tabĕhtaběhan (CXIII 3), salukat (XXIV 7), çangka (XXI 5 dan LII 6), sundari (IX 1), tabang-tabang (LX 1), dan tarayan (LX 6).

Pada Kakawin Sumanasāntaka yang dikerjakan Worsley, penulis menemukan is- tilah karawitan (instrumen musik), tersurat dalam 27 syair kakawin Sumanasāntaka seperti berikut. Pupuh IX 1 (Sundari, kĕtug), pupuh XIX 5 (garantung, taběh-taběhan), pupuh XXIV 7 (salukat), pupuh XXV 4 (padahi, taběh-tabĕhan, kĕtug, gubar, ghanta), pupuh XXVII 8 (calung), pupuh XXVIII 28 (padahi, gita), pupuh XXVIII 29 (Angigel, angindung, padahi, tabĕh-taběhan), pupuh XXXIX 2 (gěnding), pupuh XLIV 4 (taběh, titir), pupuh LII 2 (garantung), pupuh LII 6 (sangkha, tarayan, mrdangga), Pupuh LVII 3 (kendang, gong), pupuh LVII 4 (garantung), pupuh LX 1 (Menmen, tabang-tabang), pupuh CXI 6 (curing, ghanta, dan padahi), pupuh CXII 6 (tabang-tabang, kidung, kangsi, murawa), pupuh CXII 7 (mrdangga, kidung), pupuh CXIII

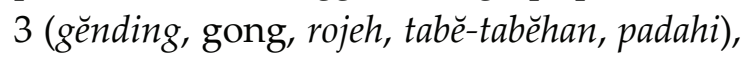
pupuh CXLIII 7 (padahi, gong, kĕtug), pupuh CXLV 10 (kětug, gubar, garantung), pupuh CXLVI 2 (nabĕh, kulkulan), pupuh CXLVI 14 (gong, padahi), pupuh CXLIX 4 (gubar, kulkulan, kangsi, mongmong), pupuh CXLIX 29 (kĕtug, gong, gumecik, galempong), pupuh CLI 5 (kětug, gubar), pupuh CLIII 39 (curing), dan pupuh CLVII 7 (garantung).

Kakawin Sumanasāntaka ceritanya sangatlah panjang terdiri atas 183 pupuh, kemudian tokoh-tokoh utamanya kurang begitu dikenal dibandingkan dengan eposepos India yang lain, dan tidak muncul dalam tradisi wayang Jawa (Zoetmulder, 1983: 386). Tokoh seperti Pangeran Aya, Brahmin Trnawindu, Bhoja, Sunandā, Dyah Harini yang dengan nama lain adalah Indumati memang tidak begitu dikenal di Jawa dibandingkan dengan nama-nama Arjuna, Bhima, Kresna, Duryudhana, Dorna, Bhisma dan lainnya. Hal yang terjadi di Jawa berbeda dengan yang terjadi di Bali, Kakawin Sumanasāntaka dibuat salinannya seperti yang diuraikannya yaitu seseorang yang bernama Ni Pangkajarwati yang telah menyelesaikan penyalinan tanggal 1 Oktober 1800 , sebuah salinan kolofon yang pertama pada 14 Juli 1537, di sima Kanaka oleh 
seseorang dengan parab Nirartha (Worsley, 2014: 25). Di Bali, Kidung Sumansāntaka adalah versi dari kakawin Sumansāntaka. Hal ini disebabkan oleh banyaknya frase yang ada dalam kidung Sumanasāntaka dicomot dari kakawin Sumansāntaka (Worsley, 2014: 27).

Kakawin Sumanasāntaka memiliki kekhasan tersendiri, karena walaupun dikarang pada zaman Erlangga, tetapi rupa-rupanya raja Erlangga bukanlah yang memerintahkan untuk menggubah Kakawin Sumanasāntaka, melainkan Sri Warsajaya. Sri Warsajaya dalam prasasti Kěting (1204 M) tertulis Sri Jayawarsa Digjaya Sāstraprabhu (Zoetmulder, 1983: 385). Yang menarik adalah kehidupan di keraton sungguh bernafaskan Jawa, sehingga penting bagi pengetahuan kita tentang sejarah Jawa Kuno (Zoetmulder, 1983: 387).

\section{METODE}

Metode sejarah sudah mulai banyak dipergunakan dalam penelitian-penelitian kesenian seperti halnya yang dilakukan oleh Nurlelasari dalam melakukan penelitian tentang Sintren. Ia mengkaji Sintren yang terdapat di wilayah Pantai Utara Jawa (Indramayu) yang memliki budaya yang serupa dengan budaya Jawa (Nurlelasari, 2017: 16). Penelitian dengan metode sejarah untuk kesenian juga dilakukan oleh Nina Herlina untuk melihat potensi seni yang dimiliki oleh Kabupaten Pangandaran, yaitu bertujuan untuk merekonstruksi sejarah seni ronggeng (Lubis, 2015: 74).

Metode sejarah Menurut Louis Gottschalk, metode sejarah adalah proses menguji dan menganalisis secara kritis rekaman dan peninggalan masa lampau. Metode sejarah terdiri atas heuristik, kritik, interpretasi, dan historiografi, dengan tujuan merekonstruksi masa lalu (Garraghan, 1957: 33-69; Gotchlak, 1975: 17-19; Kartodirdjo, 1982). Tahap pertama adalah heuristik merupakan langkah awal penelitian dimulai dari mengumpulkan berbagai sumber data yang terkait dengan masalah yang sedang diteliti, yaitu sumber tertulis berupa karya kakawin Sumanasantaka yaitu karya Worsley, P., S. Supomo, M. Fletchert, dan T.H. Hunter. Tahun 2014, Juga ditemukan tulisan berjudul Kakawin Sumanasantaka, Mati Karena Bunga Sumanasa, Karya Mpu Monaguna., Kajian sebuah puisi epik Jawa Kuno, Jakarta: Yayasan Obor Indonesia. Alasan pemilihan sumber buku ini dikarenakan telah melalui kajian filologi yang mendalam dan mendetail dan bersumber dari 10 naskah terpilih yaitu dengan kode LOr 4519, LOr 5015, LOr 5021, PNRI 22 L605, PNRI53 L848, K 612/IVb, naskah milik I Wayan Resinaya, I Wayan Leteng, Ida Bagus Pidada Mardika, dan naskah Profesor Robson (Worsley, 2014: 32). Dengan demikian, pemilihan buku Kakawin Sumanasantāka sebagai sumber utama tidak diragukan lagi kebenaran dan keabsahannya.

Tahap kedua adalah kritik melalui pengujian kredibilitas sumber atau yang disebut dengan kritik internal. Untuk menghasilkan fakta sejarah, sumber yang sudah teruji perlu mendapat pendukungan dari sumber yang lain (dua atau lebih) sumber lain yang merdeka satu sama lain dan merupakan kesaksian yang dapat dipercaya. Oleh karena itu, diperlukan koroborasi data sumber sejarah dengan sumber-sumber sejarah lebih dari satu. Tahap ketiga adalah interpretasi atau penafsiran terhadap fakta dan sumber sejarah, interpretasi dilakukan dalam dua bentuk yaitu analisis (menguraikan) dan sintesis (menyatukan). Interpretasi terdiri atas interpretasi verbal, teknis, logis, psikologis, dan faktual. Tahap terakhir adalah historiografi. Pada tahapan ini dituangkan dalam bentuk tulisan berupa laporan dalam bentuk penulisan multidimensional. Penulisan laporan lebih diarahkan kepada bentuk analitis daripada naratif atau deskriptif, karena penulisan analistis mempunyai kemampuan untuk memberi keterangan yang lebih unggul berdasarkan 
fakta-fakta yang diungkap (Santosa, 2016, 473-74; Sudirga, 2015).

\section{HASIL DAN PEMBAHASAN \\ Padahi}

Padahi adalah salah satu jenis kendang yang berbentuk tong asimetris. Beberapa ahli menyebut jenis kendang seperti ini dengan kendang yang berbentuk seperti buah jambe. Kendang dengan bentuk tong asimetris tersebar di pulau Jawa mulai dari Ujung Barat sampai Ujung Timur, Madura, Lombok, kalimantan, dan Sumatra. Di Lombok berkembang juga padaha atau kendang kerucut atau kendang yang berbentuk silinder asimetris seperti halnya kendang Bali.

Kata padahi dalam kakawin Sumanasāntaka disebut sebanyak 11 kali yaitu pada pupuh XXV 41, pupuh XXVIII 28, pupuh XXVIII 29, pupuh CXI , pupuh CXIII 3, pupuh CXLIII 7, dan pupuh CXLVI 14. Pada pupuh XXV 4, padahi disebut-sebut dengan instrumen gubar. Dikatakan Ri lampah ira ghurnita ng padahi pangharep ira kumisik mangertali tiba, Saru swara nikabarung binarungan tabĕh-taběhan agenturan kadi gereh artinya: Saat mereka berangkat, tambur kerucut di depan menggelegar seperti bunyi air terjun, ditabuh berbarengan, bunyinya hingar bingar dan disertai tetabuhan, bergemuruh seperti guntur (Worsley, 2014: 134-35). Kata padahi yang terdapat pada pupuh XXVIII 28 tersurat Padahi marek agupyan sabdanyamanis inamer. Kadi pangucap ucap ning munggw i jro jinem akule.... yang artinya tambur kerucut kini mendekat bersahut-sahutan dengan akrabnya, bagaikan percakapan dua sejoli yang bercinta di peraduan. Penulis melihat bahwa kendang dimainkan secara berpasangan, sehingga suaranya bersahutan, hal ini mengingatkan pada teknik menabuh kendang Bali yang dinamakan dengan gegulet. Padahi pada pupuh ini juga dipergunakan untuk mengiringi tembang. Pada pupuh XXVIII 29 kata padahi tersurat dengan rangkaian kata seperti berikut.

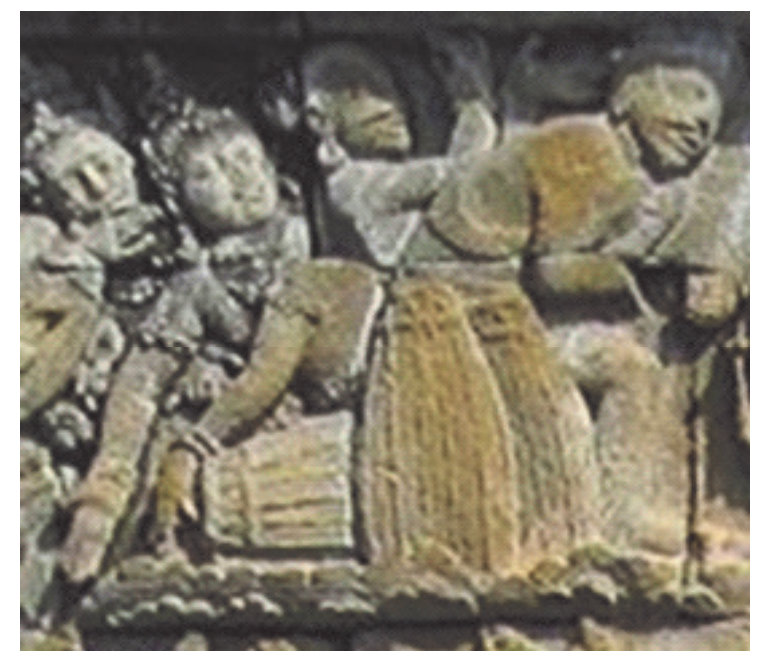

Gambar 1: Padahi relief Candi Borobudur Sumber: koleksi Tropen Museum Relief Borobudur Lalitavistara-001E.

Tucapa bala nirakweh bhawanya n panginuminum, angigel angindung asrang twaknyakweh kadi humili, padahi nika gumeter sinrang ning tabĕ-tabĕhan, kadi baribina sang hyang ring swargatukupa kapo (Worsley, 2014: 154).

\section{Artinya:}

Sekarang kami akan berbicara tentang pasukan Aja. Mereka menghibur diri dengan segala macam cara, minum-minum dan senang-senang. Ada yang menari dan menyanyikan lirik kidung, bersaing satu sama lain, sementara tuak mengalir deras tetabuhan berlomba-lomba dengan gemuruh genderang kerucut, Begitu riuh sampaisampai sepertinya para dewa di kahyangan mungkin terganggu dan menutup telinga dengan tangan (Worsley, 2014: 155).

Selanjutnya dalam pupuh CXIII 3 tersurat Saha padahi gumeter lagyatry asurak angawat yang artinya dengan gemuruh genderang kerucut yang tak henti membahanakan irama pengantar, apakah irama pengantar ini sama dengan tabuh petegak di Bali, tatalu di Sunda, atau klenengan di Jawa? Worsley menerjemahkan padahi dengan genderang kerucut. Terjemahan dari padahi, disebut dengan tambur kerucut, genderang kerucut, Wirjosuparto dalam kakawin Bharatayudha, yang mennerjemahkan kata padahi dengan kendang kerucut (Wirjosuparto, 1968: 211). Penulis berpendapat padahi adalah kendang yang berbentuk jambe (buah pinang), hal ini didasarkan kepada tersebarnya bentuk ken- 


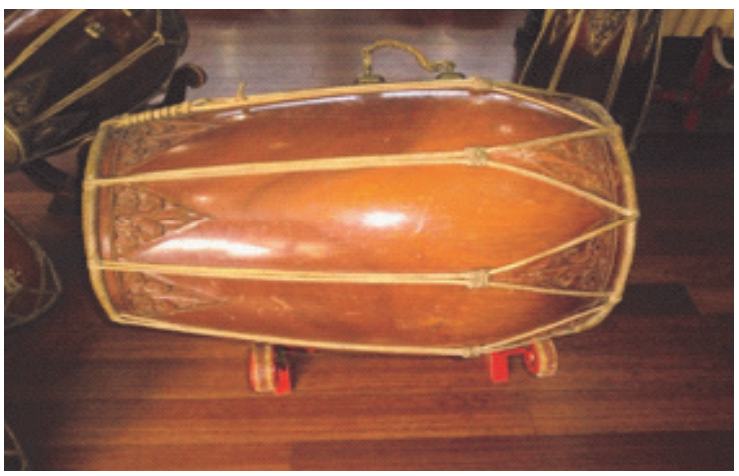

Gambar 2: Foto Kendang Bem salah satu jenis Padahi

Sumber: Dokumentasi Penulis tahun 2016

dang seperti jambe ini di seluruh pulau Jawa, sedangkan di Bali, dalam berbagai prasasti banyak ditemukan kata padaha yang artinya juga kendang, tetapi kendang yang berbentuk selinder seperti yang berkembang di Bali pada saat ini.

Pada pupuh CXI 6, padahi bersama dengan curing dan ghanta dibunyikan untuk mengiringi upacara tawur dan berhenti ketika matra Panca Brahma dilantunkan. Di Bali sekarang, satu-satunya tempat di mana kata itu masih ada, curing atau caring merujuk pada instrumen seperti gambang gangsa di bahasa Jawa. Dalam kata lain kepada sebuah metallophone multi-oktaf (Kunst, 1968: 56). Curing biasanya disebut dengan gambang gangsa dan dimainkan dengan dua angan, pada saat ini curing masih di jumpai di Bali pada gamelan Smar Pagulingan di Puri Gerenceng tetapi dimainkan seperti gangsa biasa dengan satu tangan. Berikut petikan pupuh CXI 6 Sedeng atawur ahosan ginyaken sira huwusa, curing amarengi ghantarum lalityan tan asarag, padahi ning atawur sabdanyarasmipuja-pujan, mahuwusan ihuwus ning pancabrahmana kinanaken yang artinya meski sudah berusaha keras menyelenggarakan upacara tersebut, mereka masih juga disuruh cepat-cepat menyelesaikannya, simbal mengiringi genta dengan merdu, anggun dan tenang, dan bunyi genderang kerucut pada pelaksana tawur mengiringi jalannya upacara dengan indah, genderang berhenti berbunyi setelah mantra Panca Brahma di-

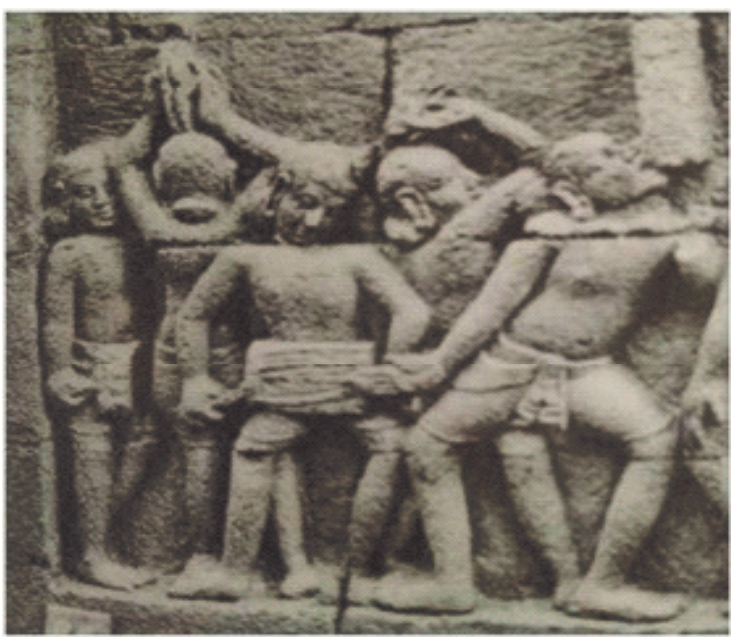

Gambar 3: Rojeh pada relief candi borobudur. Sumber: NJ Krom. 2009. Barabudur Tinjauan Arkeologi I.Vol-1.

lantunkan (Worsley, 2014: 320-321).

Pada pupuh CXLIII 7 kata padahi disertai dengan gong dan kĕtug, dipergunakan untuk mengiringi keberangkatan Sri Indumati dan pangeran Aya meninggalkan ibu kota. Salwir ikang padahing nagarasrang, ramya tekapnya hanan sinameni, len masarag makapanghada gongnya, lwir kĕtug ing lewu dennya gumeter (Worsley, 2014: 384). Artinya segala macam genderang kerucut di ibukota ditabuh bertalu-talu, bunyinya meriah diiringi sebagian orang, sementara sebagian oang lainnya penuh semangat menopang genderang yang berukuran besar genderang menggelegar keras bagai halilintar menyambar-nyambar (Worsley, 2014: 285). Penerjemahan gong menjadi genderang sebenarnya kurang tepat. Hal ini disebabkan bisa saja gong ini menunjukkan instrumen gong atau berupa sekelompok instrumen (gamelan) yang ada gong besarnya karena ada kata menopang. Kemudian ada kata kětug artinya kendang besar yang pada saat ini di Jawa disebut dengan keteg.

Pada Pupuh CXLVI 14, padahi beserta gong dipergunakan untuk mengiringi pasukan dengan senjata lengkap dan kemungkinan berjalan secara cepat dengan cara berbaris. Disampaikan seperti berikut. Para samya papregi mangkat, muni gongnya lawan padahinya, saha sanjata soh ri tegalnya... 
(Worsley, 2014: 394). Artinya para hulubalang rendah buru-buru berangkat, diiringi bunyi gong dan genderang kerucut, bersenjata lengkap, mereka memenuhi ladang (Worsley, 2014: 395).

\section{Tabĕh-tabĕhan}

Kata taběh-taběhan, tabĕh, dan naběh mempunyai pengertian adanya instrumen yang sedang dibunyikan. Kata-kata itu tersurat dalam pupuh XIX 5 bersama garantung yang menyiratkan adanya orang yang memainkan instrumen atau ensemble garantung, bisa satu orang, bisa banyak orang yang memainkannya. Seperti halnya Pada pupuh XXIX 5 kata taběh-tabĕhan dengan kata garantung yang berarti instrumen atau ensemble garantung yang sedang ditabuh. Pada pupuh XXV 4 kata tabĕh-tabĕhan ditulis bersama dengan padahi, kĕtug, gubar, dan ghanta, menyiratkan bahwa ada sekelompok orang yang memainkan berbagai jenis alat musik (gamelan). Selanjutnya dalam pupuh XXVIII 29 kata tabĕh-tabĕhan padahi. bersama kata angigel, angindung, seperti tersurat ... angigel angindung asrang twaknyakweh kadi humili, padahi nika gumeter sinrang ning tabĕ-tabĕhan ... (Worsley, 2014: 154). yang artinya ada yang menari dan menyanyikan lirik kidung, bersaing satu sama lain, sementara tuak mengalir deras, tĕtabuhan berlomba-lomba dengan gemuruh genderang kerucut (Worsley, 2014: 155). Kata padahi menyiratkan adanya sekelompok instrumen (gamelan) dengan hanya menyebut instrumen utamanya saja (padahi) yang difungsikan untuk mengiringi sebuah pesta yang meriah. Gamelan padahi ini difungsikan untuk mengiringi tarian dan untuk mengiringi nyanyian.

Selanjutnya kata tabĕh dalam pupuh XLIV 4 bersama titir seperti tersurat ... nika kirana ni musuh irătaběh titir (Worsley, 2014: 198), yang diterjemahkan itulah sebabnya musuhnya memukul kentongan terus menerus (Worsley, 2014: 199). Penerjemah-

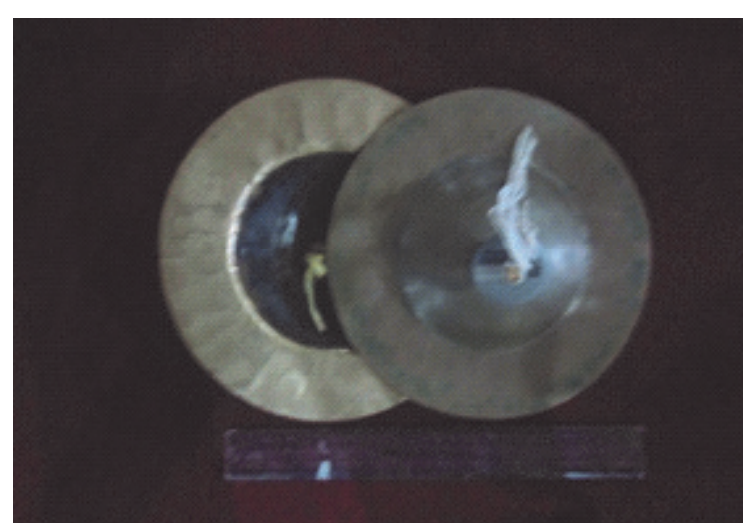

Gambar 4: Cengceng/rojeh

Sumber: Dokumentasi Penulis pada 2016

an tabĕh dengan kentongan hemat penulis kurang tepat hal ini kemungkinan dari kebiasaan sekarang bahwa yang ditabuh secara nitir atau titir adalah kentongan. Namun bisa saja yang ditabuh itu bende, mrdangga, kala, gubar, atau instrumen yang lain. Kata nitir atau titir berarti secara cepat, konstan dan secara terus-menerus, biasanya untuk tanda bahaya atau juga peperangan. Mungkin pengertian kentongan ini bisa dipergunakan untuk pupuh CXLVI 2, dimana kata nabĕh bersama kulkulan, seperti tersurat juru samya dateng pangatagnya, $i$ samangjuru len para duhwan, pada sambhrama marma padagya anaběh kukulan makapentok (Worsley, 2014: 394). yang artinya: Para panglima dan hulubalang rendah datang, memanggil sekutu mereka dan para kepala dusun, mereka sangat bersemangat sehingga cepat-cepat memukul kentongan tanda bahaya (Worsley, 2014: 395). Selanjutnya pada pupuh CXIII 3 kata tabĕh-taběhan ber-sama kata gĕnding, gong, rojeh, padahi, seperti tersurat ... para ratu saha gĕnding gong rojeh tabĕ-taběhan, apituwi para tandasrangsangan mider aritan, saha padahi gumeter lagy atry asurak angawat (Worsley, 2014: 328). Terjemahnnya: ... para raja beserta tabuhan gong dan simbal, lebih-lebih lantaran para pejabat tanda berlomba-lomba berseliweran di tengah kerumunan orang, dengan gemuruh genderang kerucut yang tak henti membahanakan irama pengantar (Worsley, 2014: 329). Paling menari dengan adanya 
kata rojeh yang berarti simbal. Pada saat ini simbal atau rojeh ini sangat dominan dalam gamelan Balaganjur.

\section{Sundari}

Instrumen ini termasuk pada kelompok yang dibunyikan bukan oleh manusia tetapi dengan bantuan tiupan angin. Sundari terdiri atas satu buah bambu dengan berbagai bentuk lubang yang dipotong di dalamnya, dan biasanya ditempatkan jauh tinggi di pohon atau ditancapkan begitu saja di pematang sawah. Ketika tiupan angin mengenai lubang maka akan menghasilkan bunyi yang cukup menyenangkan dengan kunci nada berbeda yang bisa didengar dari jarak jauh (Kunst, 1968: 26). Dengan kata lain, sundari adalah flute Aerolian. Di dalam cerita wayang suara dari sundari ini biasanya diasosiasikan pada tangisan putri. Namun, dalam kekawin Sumanasāntaka diibaratkan dengan tangisan capung. Sundari pada Jawa modern disebut sendaren, di Sunda disebut sondari. Berikut kata sundari dalam pupuh IX 1. Humung tangis i sundari nikang alas hinariwuwu ni sabda ning gagung, artinya: Capung menangis meraung-raung di hutan dan dilipur suara katak (Worsley, 2014: 82-83).

Terjemahan Sundari dengan capung adalah untuk membuat perumpamaan karena memang suara yang keluar dari Sundari seperti suara tangisan. Sundari disebut pula dengan sundaren, sendaren, sendari, atau juga sawangan layangan. bentuk adalah bahwa dari busur bambu, berlangsung ketat oleh serangkaian baik bulu kuda atau tape serat rotan sangat tipis. Busur ini terpasang di sisi melengkung untuk layang-layang (layangan), sedemikian rupa bahwa busur dan lintas pita layang-layang pada bidang yang sama. Ketika layang-layang sudah di udara senar sundaren yang dibuat berbunyi karena tertiup angin (Kunst, 1973: 232). Di Bali dikenal dengan sunari yang dipasang di pematang sawah, para petani acapkali menancapkan sebatang bambu yang dilubangi di beberapa bagiannya yang disebut dengan sunari. Jika tertiup angin, akan mengalunkan suara yang merdu.

\section{Garantung}

Kata garantung terdapat dalam pupuh XIX 5 (garantung, tabĕh-tabĕhan), pupuh LII 2 (garantung), pupuh LVII 4 (garantung), pupuh CXLV 10 (kĕtug, gubar, garantung), dan pupuh CLVII 7 (garantung). Kata garantung ada yang berdiri sendiri dan ada juga yang diikuti oleh instrumen yang lainnya. Membaca pupuh XXIX 5 tersurat Abwat-hajyan ikang humung saha garantung atebe-tabĕhan padaselur, agya lagy anguluh sire harep alah laku-laku ikang hane wuri (Worsley, 2014: 120). Terjemahannya: Arak-arakan pembawa sumbangan untuk hajatan kerajaan menimbulkan kegaduhan diiringi bunyi garantung yang dipukul bertalu-talu. “Cepat!" Teriak mereka yang di depan berulang-kali. Ayo, cepat jalan!" teriak mereka yang di belakang (Worsley, 2014: 121). Kata garantung di sini berbeda dengan apa yang ada pada pupuh lainnya yaitu adanya iringan kata bertalu-talu, gaduh dan sepertinya dipergunakan dalam sebuah prosesi karena kata "cepat" dan "ayo, cepat jalan". Ini menandakan bahwa garantung dipergunakan untuk memberikan semangat atau respon fisik kepada orang yang melakukan arak-arakan, apalagi ada panji-panji yang dibawa. Fungsi garantung dalam pupuh XXIX 5 sepertinya tidak jauh dengan fungsi yang ada pada pupuh LII 2, dimana tersurat ... Sakweh ning kapapag lumingsir aweding wwang ahelap akemul ya ring wengi panjut sanjata len garantung $i$ harep prakata bangun akon suminggaha (Worsley, 2014: 224), yang artinya: Semua orang yang berpapasan dengan mereka menepi, terbungkus melawan dinginnya udara malam, orang-orang ini kagum terhadap para wanita yang begitu bergaya, lampu, senjata, dan garantung bergemuruh yang berjalan di depan mere- 
ka seolah memerintahkan orang-orang minggir (Worsley, 2014: 225).

Kata garantung juga terdapat dalam pupuh LVII 4 seperti tersurat Mangkat Srindumati garantung ira muny asemu gula ghinasa ring waja yang artinya Sri Indunmati berangkat, garantung-nya terdengar semanis gula digosokkan pada gigi (Worsley, 2014: 236-237). Pupuh ini memperlihatkan adanya dua istilah alat musik yaitu garantung dan tabĕh-tabĕhan. Garantung dalam pupuh ini ditabuh di alun-alun dan dipergunakan untuk menyambut kedatangan Indumati dan pangeran Aya.

Pada pupuh CXLV 10 dimana kata kĕtug diikuti oleh kata gubar dan garantung seperti yang tersurat:

I sampun ira munggah ing ratha tumut nrpawaraduhita hane wuri, pasanggha ni surak watek raghusutamaji talinga nikang wwang angrengo, linud $i$ këtug ing gubar saha garantung uni nika karengw anglw-alo, ikang wwang apeken-peken gumuruh awreg inawaran i duta ning musuh (Worsley, 2014: 394).

\section{Terjemahannya:}

Setelah Pangeran menaiki kereta perang, sang putri mengikuti, deru teriakan bala tentara memekakan telinga, demikian pula gelegar gong gubar dan garantung, orangorang yang bedagang di pasar kalang-kabut, dikacau mata-mata musuh (Worsley, 2014: 395).

Dikatakan bahwa bunyinya memekakkan telinga, karena ada kětug, yang di Jawa dikenal dengan keteg yaitu kendang besar, maka garantung yang dimaksud di sini pasti bukan garantung yang suaranya manis tetapi suaranya keras dan menakutkan sehingga orang-orang menjadi kalang kabut.

Selanjutnya kata garantung juga terdapat dalam pupuh CLVII 7 seperti tersurat ... abyungan kumisik garantung ira ramya kadi papgut ing ryak ing pasir (Worsley, 2014: 440) yang artinya ...sejumlah besar garantung terdengar merdu seperti suara ombak memecah pantai (Worsley, 2014: 441). Penulis mempunyai keyakinan bahwa yang dimaksud dengan garantung yang ter- surat dalam pupuh LVII 4 dan pupuh CLVII 7disini adalah sejenis instrumen musik yang terbuat dari tabung bambu, disusun dengan cara digantung bisa menggunakan tempat seperti standar, semacam ancak atau pelawah, yang di Bali dikenal dengan nama gamelan Rindik.

Istilah garantung sendiri memiliki arti instrumen musik yang digantung. Instrumen musik apa yang digantung dan dibunyikan dengan cara dipukul. Di nusantara sebenarnya banyak instrumen atau gamelan yang penempatannya dengan cara digantung. Misalnya seperti di Kalimantan tengah, sekumpulan kempur digantung dinamakan dengan garantung (Kunst, 1968: 69) yang terdiri dari 5 nada. Garantung di desa Bayan Lombok utara adalah nama gamelan yang terdiri atas dua buah gong yang digantung, empat buah pencon yang ditempatkan dalam dua buah standar (pangkon), dan dua buah gendang berbentuk selinder mirip gamelan Balaganjur tetapi tanpa menggunakan ceng-ceng. Teknik tabuhannya tidak seperti gamelan Balaganjur. Melihat fungsi garantung yang diutarakan pada pupuh di atas dimana gamelan dipergunakan untuk peperangan, maka pengertian garantung adalah kelompok instrumen kempul/bende/ gubar sebagai penggugah respon fisik dan juga ada aba-aba yang memerintahkan untuk berjalan cepat dan panji-panji yang di bawa. Selanjutnya di Batak Toba, garantung adalah sejenis xilofon terbuat dari bilahan kayu (Kunst, 1973: 72).

Pada pupuh XXVII 8 tersurat Humili wulakanya pa calunganeka katon humadang yang artinya mata air mengalir, dan air yang diciduk dalam bumbung sudah siap. Calung dipergunakan untuk membawa air, apakah hal ini dimaksudkan bahwa calung selain dipergunakan untuk bermain musik, juga untuk membawa air? Calung adalah instrumen yang terbuat dari tabung bambu yang dimainkan secara dipukul. Di Sunda ada dua macam calung pertama calung jinjing 
karena tabungnya ditusuk bambu, dipegang tangkainya dan dimainkan dengan cara dipukul. Calung jinjing terdiri atas calung Kingking (terdiri dari 12 tabung bambu), calung Panepas (5 tabung bambu), calung Jongjrong (5 tabung bambu), dan calung Gonggong (2 tabung bambu). Kedua calung rantay karena tabung-tabung bambu tersebut diikat terkadang dibuatkan standar seperti gambang untuk mempermudah memainkannya. Di daerah Banyumas, gamelan calung dibuat dengan menggunakan standar dengan menggunakan laras Slendro. Istilah calung juga dikenal di Bali merujuk pada salah satu jenis gender perunggu, sedangkan nama batak xilofon bambu adalah garantung (Kunst, 1968: 72). Penulis pernah melihat sebuah video pertunjukan Angklung yang menggunakan calung dari bilah bambu, dimainkan dengan dua tangan. Namun sepertinya ada perbedaan penamaan garantung dan calung antara Sunda, dengan Batak, Kalimantan Tengah, Bayan Lombok, dan Bali.

Jaap Kunts dalam bukunya Hindu Javanese Musical Instrument menyebutkan bahwa pada pupuh XXI 5 tertulis kata çangka, namun setelah ditelusuri ternyata tidak ditemukan. Berikut disampaikan pupuh XXI 5

Antuk sang priya mangdaweken inalem para kawi sumenaha ring kajang. Yeki $n$ rakwa kinonya kady angucapamah aku thuan alap waca nghulun. Mogha nyan ya kinonaken wacan ika ri pamanca nika mangdadak lumuh. Swaminyadadi pustakanuturaken hidep ika pinapagnya ring tangis (Worsley, 2014: 122).

Terjemahannya:

Karya puisi kekasihnya, yang dipuji para penyair, tergolek menunggu di atas bantal. Kata orang, dalam puisi itulah sang kekasih menyuruhnya, seakan berkata "ini aku Dinda! Terimalah kata-kataku!" Begitulah ia disuruh membaca apa yang ditulis kekasihnya, dan setelah membacanya, dia menangis. Kekasihnya, yang telah menjadi kitab pendamping pikirannya, disambut dengan air mata (Worsley, 2014: 123).

\section{Salukat}

Pupuh XXIV 7 menyuratkan instrumen salukat. Tan sah ring salukat gawe nrpatiputra sinalukatakenya tan humung, ramyuram karengo manisnya sinameni pamawan ika ringrang ing hati, tan samwas ginarut-garutnya hinidepnya san Aja sahasangisawaken (Worsley, 2014: 132). Artinya: tak henti-hentinya ia memainkan salukat buatan pangeran dengan lembut. Salukat itu begitu halus dan enak didengar, kemerduannya mengusung gejolak di hatinya. Dia terus memetik salukat, berkhayal di pangku pangeran Aja (Worsley, 2014: 133). Mengungkapkan bahwa pangeran Aya tidak henti-hentinya memainkan salukat, suaranya merdu, halus dan enak didengar, hal ini disetujui oleh Kunts yang mengungkapkan bahwa salukat adalah nama dari sebuah instrumen gamelan (Kunst, 1968: 86). Selanjutnya penulis kurang setuju terjemahan dari Tan samwas ginarut-garutnya hinidepnya san Aja sahasangisawaken yaitu dia terus memetik salukat, berkhayal dipangku pangeran Aya.

Terjemahan ini mengungkapkan bahwa salukat dibunyikan dengan cara di petik, padahal kata salukat dalam baris ke empat tidak ada. Hemat penulis, bait yang keempat adalah sebuah hayalan seorang gadis seandainya dia itu adalah sebuah instrumen musik yang dipangku dan di dipetik atau digaruk-garuk (ginarut-garutnya) oleh pageran Aya. Salah satu instrumen pada gamelan Degung yang dinamakan dengan cecempres atau juga disebut dengan salukat. Salukat dimainkan dengan cara dipukul menggunakan alat seperti palu yang terbuat dari kayu dengan satu tangan dan tangan yang satunya menjadi alat untuk menutup gaung dari bunyi yang keluar. Instrumen ini biasanya terdiri atas 14 bilah yang tersusun dalam sebuah rancak atau pelawah yang ditahan dengan semacam paku (dipacek).

\section{Gubar}

Kata gubar terdapat dalam tiga pupuh yaitu pupuh XXV 4 (padahi, tabĕh-tabĕhan, 


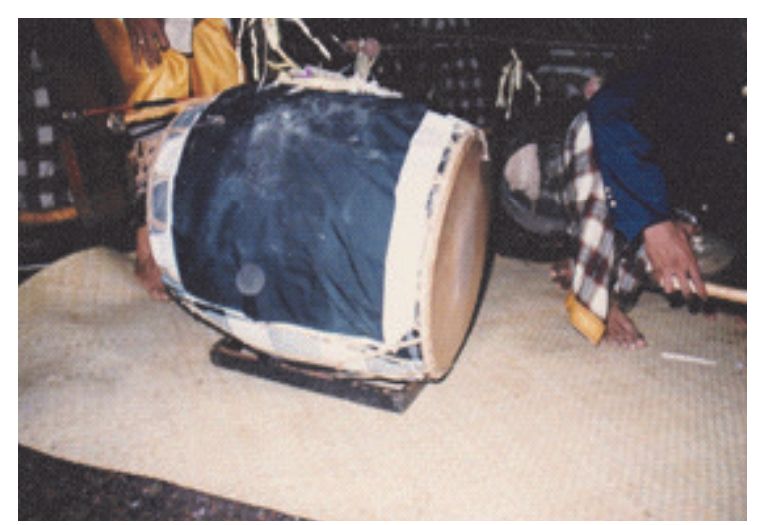

Gambar 5: Mredangga/Bedug

dalam gamelan Gong Bheri.

Sumber: Dokumentasi penulis pada 2001.

kĕtug, gubar, ghanta), pupuh CXLV 10 (kĕtug, gubar, garantung), dan pupuh CLI 5 (kĕtug, gubar) tersurat Teg tok lwir garudadahem kĕtug ikang gubar asahuran apratidhawani. Artinya: Gooooong gungngng! Gelegar gong gubar yang menggema besahut-sahutan terdengar seperti elang batuk.

Instrumen gubar tidak bisa berdiri sendiri, tetapi selalu didampingi oleh instrumen yang lain. Misalnya pada pupuh XXV 4, gubar ditabuh bersamaan dengan bunyi-bunyian (tabĕ-tabĕhan) yang lain seperti padahi, ghanta, dan kĕtug. Kunts mengungkapkan bahwa gubar diduga adalah nama lain gong menengah. Pada awal abad ke-11, suara instrumen ini digambarkan sebagai matempur yang rupanya berhubungan dengan kata kempur atau kempul (Kunst, 1968: 69). Perkiraan penulis Gubar adalah sejenis gong kecil dan suaranya nyaring, mungkin itu adalah instrumen bende di Sunda dan Jawa, di Bali ini disebut dengan tawa-tawa merupakan instrumen yang bunyinya paling nyaring dibanding dengan instrumen lainnya karena fungsinya sebagai pengatur tempo. Jika instrumen tawa-tawa ini dibunyikan, suaranya dapat mengguncang jantung, persis seperti yang disebutkan kumetug asring aniru kĕtug ing hudan wahu dawuh, (bagai guguran bola api, bertalutalu seperti derai hujan), inilah ungkapan seorang pujangga dalam membuat perumpamaan. Pada pupuh CXLIX 4 tersurat Gen- tor i sabda ni gubarnya bangun silih prep artinya: Gemuruh gong gubar terdengar seolah saling menyerang.

\section{Mrĕdangga}

Kata madanggi (mrĕdangga) untuk pertama kali disebut dalam prasasti Sri Kahulunan (842 M). Selanjutnya dalam kata madanggi tidak lagi dapat ditemukan dalam prasasti yang bertalian dengan pembebasan tanah perdikan karena sudah berganti dengan kata padahi seperti dalam prasasti Waharu I tahun 873 M, Prasasti Mulak 878 M, Prasasti Kwak I 879 M, dan Prasasti Poh tahun 905 M (Haryono, 2006: 4-5).

Mrĕdangga menurut hemat penulis ada dua pengertian, pertama yaitu sekelompok alat musik (gamelan) yang dinamakan dengan menggunakan nama dari sebuah instrumennya yaitu mrĕdangga, kedua adalah sejenis kendang yang gemuk seperti tong anggur Kunst menyebutnya symmetrical barrel shaped dan symmetrical barrel-shaped dan tentunya dengan bentuk yang lebih besar. Pada Kakawin Sumanasāntaka terdapat pada Pupuh LII 6 yang berbunyi Sangkha mwang tarayan mrdangga kumisik talinga ning wwang angrengo, artinya: Sangkakala, terompet, dan mrdangga menggelegar memekakkan teli-

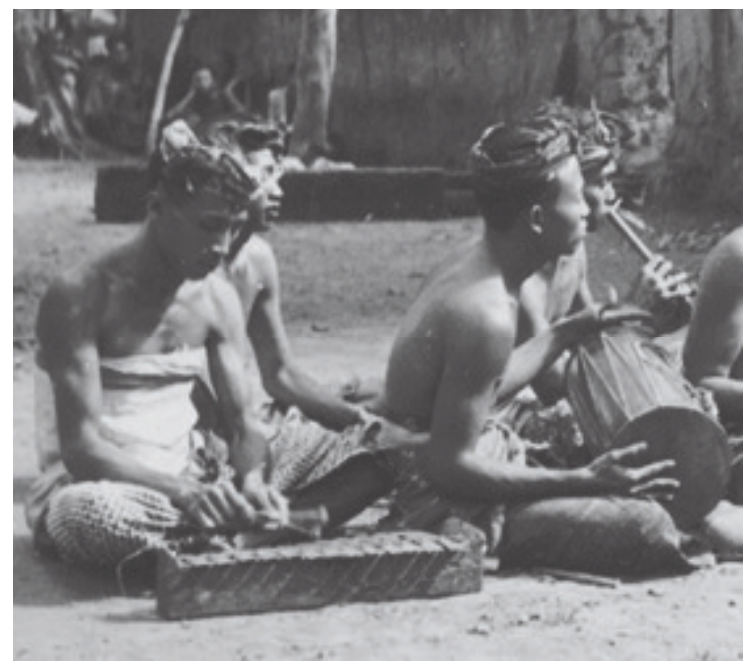

Gambar 6: Curing pada gamelan Geguntangan di Singapadu 1931-1938.

Sumber: Mc Phee, 1966. Music in Bali. http://edwardherbst.net/wpcon tent/up-loads/2016/06/1Gegun tangan-Singa-padu.jpg 
nga (Worsley, 2014: 226-227). Mrdangga juga terdapat pada Pupuh CXII 7 yang berbunyi: Mrdangga sampun sumeneha pangruhun, hanatakep len sinameni ring kidung, ndek-endekan praya ni de nika muni, lengeng karengo asemu panggyat ing jawuh. Artinya: Para penabuh mrĕdangga berdiri tegap di depan arak-arakan, ada yang menepuk-nepuk, sementara yang lainnya diiringi tembang, mereka yang menembang bermaksud melantunkan gending pengantar, sedap didengar seperti hujan badai yang turun mendadak.

\section{Curing}

Kata curing dalam kakawin Sumanasāntaka disebut dalam dua pupuh yaitu pupuh CXI 6 dimana kata curing diikuti dengan kata ghanta dan padahi. Sedangkan pada $p u-$ puh CLIII 39, instrumen curing berdiri sendiri. Pada pupuh CXI 6 curing, ghanta, dan padahi dipergunakan dalam sebuah upacara. Pada pupuh CLIII 39 yang tersurat ... tekwan huwus kacuringan rah i tungtung ing hru, yeka silunglung ira yang kaparajayeng prang (Worsley, 2014: 432), yang artinya apalagi simbal curing terdengar, dan darah membasahi ujung anak panah, sebab inilah wadah untuk jasad mereka yang kalah dalam palagan saat menempuh perjalanan ke alam baka (Worsley, 2014: 432).

Hemat penulis, curing pada pupuh ini dipergunakan untuk pengantar jasad saat menempuh perjalanan ke alam baka. Pe-

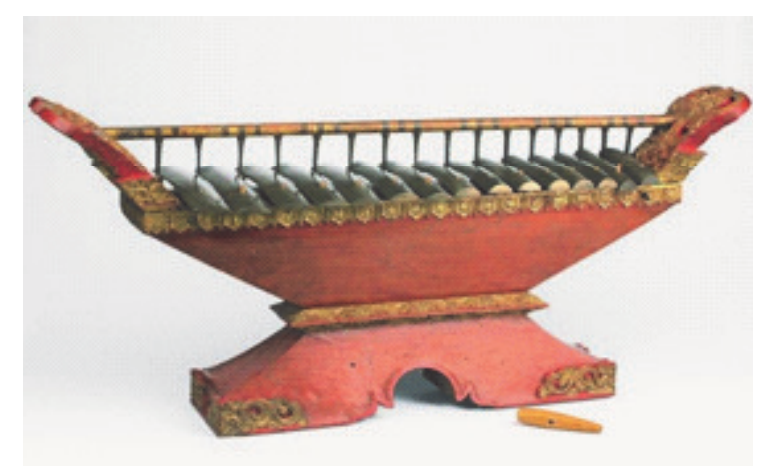

Gambar 7: Curing atau gambang gangsa dalam gamelan Smarpagulingan. Sumber: Koleksi tropenmusem gambar nomor TMnr 1340-28 nerjemahan curing sebagai sebuah simbal sepertinya mengacu pada instrumen celuring atau tuwung di yogya yang berbentuk seperti piala (Kunst, 1968: 51). Di Bali sekarang curing merujuk pada instrumen seperti gambang gangsa pada bahasa Jawa. Dalam kata lain kepada sebuah metallophine multioktaf (Kunts, 1968: 56).

\section{Kendang, Gong, Rebana, dan Instrumen lainnya}

Kata kendang dan gong tersurat dalam Pupuh LVII 3 yang berbunyi: Kendang gong muni t angkat-angkat atereh dhwani nika karenggo sake yawa, artinya: Kendang dan gong berbunyi, "berangkat! berangkat!" begitu nyaring dan menggelegar hingga terdengar dari luar kerumunan orang (Worsley, 2014: 236-237).

Kemudian instrumen rebana/terbang terdapat pada Pupuh LIX 1, dimana Jaap kunts menyebut pada LX 1 yang berbunyi: Hyang ning gita tekanurun kahidepannya dateng iniring ing tabang-tabang, artinya: Mereka dianggap sebagai Dewi Gita yang turun diiringi rebana (Worsley, 2014: 238239). Kemudian pada pupuh CXII 6 yang berbunyi: Alakwa-lakwan paripurna ring halep, tabang-tabang ramya kerengw awangsulan, kidung kinangsyan murawanya tan humung, lalitya tan kaskasa sangsayararas, yang artinya: Dalam arak-arakan, mereka sempurna paripurna, rebana bersahut-sahutan meriah, gong kangsi mengiringi kidung, sementara gendang murawa terdengar lembut, tidak kasar, tapi halus dan makin merdu (Worsley, 2014: 327).

Pada Pupuh CXLIX 29, tersurat gong seperti berikut: Carcab lebik bek adu gong gumecik gelempong, yang artinya: Carcab lebikbek adu gong gumicik gelempong. Pada Pupuh 39 No. 2 terdapat kata gending yang diartikan sebagai gamelan. Adapun syairnya tersurat sebagai berikut. Padakundang gĕnding gumereh aselur tan papegatan, artinya Mereka tiba diiringi bunyi gamelan menggelegar yang dimainkan tanpa henti. 


\section{Kulkul}

Instrumen kulkul tersurat dalam dua pupuh yaitu pupuh CXLVI 2 dan pupuh CXLIX 4. Pada pupuh CXLVI 2 tersurat juru samya dateng pangatagnya, $i$ samangjuru len para duhwan, pada sambhrama marma padagya, naběh kukulan makapentok. Artinya: Para panglima dan hulubalang rendah datang, memanggil, sekutu mereka dan para kepala dusun, mereka sangat bersemangat sehingga cepat-cepat, memukul kentongan tanda bahaya.

Kemudian pada Pupuh CXLIX 4 Basantatilaka tersurat: Gentor i sabda ni gubarnya bangun silih prep, kady acakep dhwani nikang kulkulan karesres, kangsinya lagi manah ambek ing ajrih ing prang, mongmongan anggyat anamar macan asring olih. Artinya: Gemuruh gong gubar terdengar seolah saling menyerang, gema seram kentongan terdengar seakan memukuli bibir. kangsi berulang kali memanah orang-orang yang terlalu takut melawan. Terlihat bahwa kulkul dipergunakan untuk memberikan tanda bahaya.

\section{Fungsi Gamelan Bali}

Bandem mengungkapkan bahwa Gamelan Bali memiliki fungsi yang sangat penting dalam kehidupan masyarakat. Mengacu pada Hasil Seminar Seni Sakral dan Profan dalam bidang Tari pada 1971 yang mengelompokan fungsi seni menjadi seni wali (sakral), bebali (semi sakral), dan balih-balihan (sekuler). Menurut Usana Bali - Usana Jawa, kesenian Bali muncul sebagai wewalen (seni keagamaan) semata. Berhubung dengan adanya perubahan zaman dan waktu, kesenian Bali bergeser pula dari seni wali menjadi seni bebali dan seni balih-balihan. Seni wali lahir di jeroan pura (utama mandala), seni bebali lahir di jaba tengah (madya mandala) dan seni balih-balihan lahir lahir di jaba pura (nista mandala). Setiap kelompok seni memiliki wujud, sifat (karakter), perlengkapan, dan upakara yang berbeda menurut adigum desa (tempat), kala (waktu) dan patra atau kondisi (Bandem, 2013: 113).

Berdasarkan pengertian dan pemahaman kegunaan dan fungsi yang dirumuskan oleh Alan P. Merriam dimana kajiannya pada musik Basonge di Afrika, dia menyebutnya sebagai suatu lambang dari hal-hal yang berkaitan dengan ide-ide maupun perilaku suatu masyarakat (Merriam, 1964: 32-33). Dalam chapter XI tenang kegunaan dan fungsi diungkapkan sepuluh kegunaan dan fungsi musik yaitu pengungkapan emosional, penghayatan estetis, hiburan, komunikasi, perlambangan, reaksi jasmani, fungsi yang berkaitan dengan norma sosial, pengesahan lembaga sosial, kesinambungan budaya, dan fungsi pengintegrasian Masyarakat.

Selanjutnya Bandem merumuskan sembilan kegunaan dan fungsi gamelan Bali yaitu sebagai pengiring upacara, memberi rasa keindahan, sebagai alat komunikasi, sebagai hiburan, persembahan simbolis, menggugah respon fisik, mengukuhkan norma-norma kehidupan masyarakat, pengungkap sejarah, dan makna pendidikan (Bandem, 2013: 114118). Apa yang disebutkan Bandem, tentu saja berdasarkan atas pengamatan dan pengalaman terhadap peristiwa-peristiwa yang telah dilaluinya yang terjadi pada masa kini. Peristiwa-peristiwa berkesenian itu tentunya sangat membekas dalam jejak perjalan-an kehidupan beliau.

Fungsi gamelan/instrumen musik pada masa yang lampau dapat dilihat dari berbagai artefak, prasasti, dan kesusastraan kuno. Untuk melihat fungsi tersebut, Fieter Edward Johanes Ferdinandus telah menguraikannya dalam fungsi ensambel (gamelan) dalam masyarakat Jawa Kuna. Ferdinandus membagi dua fungsi ensambel yaitu sebagai upacara sakral dan ensambel sebagai sarana kegiatan sekuler. Ada tujuh jenis kegiatan sekuler yaitu hiburan, komunikasi, penghormatan, perang, ekonomi, mas kawin, dan simbol. 
Ferdinandus menyebutkan bahwa instrumen musik adalah sebagai sarana tontonan sekuler terdapat dalam data relief, prasasti dan kesusastraan. Dalam data relief peran ensambel dibagi empat kelompok yaitu sebagai penghibur, pengujian, mata pencaharian hidup untuk memenuhi kebutuhan ekonomi, dan sebagai media komunikasi tentang adanya peristiwa penting (Ferdinandus, 2004: 378-403).

Fungsi ensembel dalam kegiatan sakral terlihat dari relief-relief candi Borobudur diperoleh petunjuk, sarana peralatan ritus dalam agama Budha diperlihatkan dengan jelas. Relief-relief tentang mahluk dewa yang memuja Bodhisatwa dipahatkan dalam Candi Borobudur seperti adegan Karmawibhangga, Lalitawistara, Awadhana Jataka, Gandhawyuha. Relief pada Candi Jago digambarkan upacara dewapuja di Budhicitta oleh para gandarwa dan asparaaspari (Ferdinandus, 2004: 383).

\section{SIMPULAN}

Beberapa istilah yang terkait dengan karawitan yang telah diteliti oleh para peneliti terdahulu terkadang sulit dilacak kebenarannya dikarenakan beberapa hal misalnya sumber naskah yang dipergunakan berbeda, sulit untuk diketemukan, atau telah berubah bentuknya dari puisi menjadi prosa, bentuk puisinya berubah, ataupun karena penyalinan yang kurang teliti. Hal ini terjadi karena belum ada mesin cetak sebagai pengganda naskah.

Penelitian ini juga mengungkapkan bahwa penyebutan kelompok instrumen (ensambel) ataupun hanya nama instrumen menguatkan bukti bahwa pada saat naskah-naskah tersebut ditulis, menerangkan bahwa nama dari sebuah instrumen gamelan juga merupakan nama panggilan bagi sekelompok instrumen (gamelan). Jadi apa yang terjadi di Bali dan daerah lain seperti penyebutan angklung, gambang, degung, calung, dan lainnya masih berdasarkan kaidah yang berlaku pada masa Jawa
Kuno yang bertahan sampai sekarang.

Bentuk-bentuk instrumen yang tersurat pada naskah Jawa Kuno, pada saat ini sebagian besar masih bertahan bentuknya, bahkan dari sisi pengaruh teknologi musik sudah mengalami perkembangan sehingga menghasilkan bunyi yang diingikan (lebih baik). Perubahan bentuk instrumentasi, di samping pengaruh teknologi pembuatan instrumen yang semakin maju, juga karena berbagai pengaruh dari internal dan eksternal. Pengaruh internal karena keinginan perubahan dari si senimannya sendiri sedangkan perubahan dari eksternal karena ada unsur lain seperti pengaruh politik.

Fungsi dan makna instrumen pada masa ditulisnya naskah-naskah Jawa kuno, hampir sama seperti saat sekarang dimana instrumen gamelan dipergunakan seperti untuk upacara keagaamaan, dan yang bersifat hiburan. Pada masa sekarang ada fungsi dan makna yang hilang yaitu fungsi sebagai gamelan perang yang selanjutnya menjadi gamelan untuk upacara.

\section{Daftar Pustaka}

Bandem, I. M. (2013). Gamelan Bali di atas Panggung Sejarah. Denpasar: Badan Penerbit STIKOM Bali.

Ferdinandus, P. E. J. (2004). Alat Musik Jawa Kuno. Yogyakarta: Yayasan Mahardika. Garraghan, S. J. G. (1957). A Guide to Historical Method,. (J. Delanglez, Ed.). New York: Fordham University Press, East Fordham Road, Fourth Printing.

Gotchlak, L. terjemahan N. N. (1975). Mengerti Sejarah (Pengantar Metode Sejarah). Jakarta: Universitas Indonesia.

Haryono, T. (2006). Sejarah Seni Pertunjukan dalam Perspektif Arkeologi. Yogyakarta: Makalah disampaikan pada Diskusi Sejarah dengan tema Sejarah Seni Pertunjukan dan Pembangunan Bangsa, diselenggarakan oleh Balai Kajian Sejarah dan Nilai Tradisional. 
Kartodirdjo, S. (1982). Pemikiran dan Perkembangan Historiografi Indonesia, Suatu Alternatif. Jakarta: PT Gramedia.

Kunst, J. (1968). Hindu Javanese Musical Instruments. The Hague: Martinus Nijhoff.

Kunst, J. (1973). Music in Java, Its History, Its Theory, and Its Technique, Third Englard edition, volume I. The Hague: Martinus Nijhoff.

Lubis, U. A. D. N. H. (2015). Perkembangan Ronggeng Sebagai Seni Tradisi di Kabupaten Pangandaran. Panggung, 25(1), 71-80. Retrieved from https:// simlitmas.isbi.ac.id/e-jurnal/index. php/panggung/article/view/16/20.

Merriam, A. P. (1964). The Antrhopology of Music. Northwestern: University Press.

Nurlelasari, N. H. K. S. D. (2017). Seni Pertunjukan Sintren di Kabupaten Indramayu dalam Perspektif Historis. Panggung, 27(1), 15-25.
Santosa, H., Kustiyanti, D., \& Sudirga, I. (2016). traces of musical instruments in kakawin bharatayudha. E-Journal of Cultural Studies, 9, No.2. Retrieved from https://ojs.unud.ac.id/index. php/ecs/article/view/35695

Sudirga, H. S. D. K. K. (2015). Jejak Karawitan dalam Kakawin Arjuna Wiwaha: Kajian Bentuk, Fungsi dan Makna. Segara Widya, 3(1), 471-481.

Wirjosuparto. (1968). Kakawin Bharata-Yudha. Yudha. Djakarta: Penerbit Bhatara.

Worsley, P. J. (2014). Kakawin Sumanasantaka, Mati Karena Bunga Sumanasa, karya Mpu Monaguna, Kajian Sebuah Puisi Epik Jawa Kuno. Jakarta: Ecole Francaise d'Extreme-Orient Koninklijrk Instituut voor Taal Land en Volkenkunde, Yayasan Obor Indonesia.

Zoetmulder, P. (1983). Kalangwan, Sastra Jawa Kuno, Selayang Pandang (Terjemahan). Bandung: Djambatan. 